\title{
Articles
}

\section{Synthesis and Pharmacological Studies for New Benzotriazole and Dibenzodiazepine Derivatives as Antipsychotic Agents}

\author{
Osama I. EJ-Sabbagh ${ }^{\star}$ and Sameh M. El-Nabtity๋ \\ Department of Medicinal Chemistry: Factlty of Pharmacv, Zagazig Lniversity, 44511, Zagazig, Egypt \\ ${ }^{*}$ E-mail: elsabbagh_59iâuhoo.com \\ ${ }^{\dagger}$ Department of Phamacology, Factlty of Teterinary Aledicine, Zagazig Lniversity, 44511, Zagazig, Egvpt \\ Recerved April 29, 2009, Accepted Hav 23, 2009
}

\begin{abstract}
New benzotriazoles (5-8) or dibenzodiazepine derivatives (11-18) were synthesized starting from 3-[(2-amino4,5-disubstitutedpheny l)anino]-5,5-disubstitutedcyclohex-2-enones (1-4) through internal coupling of their diazonium salts or intemal Hamich reaction in the presence of aromatic aldehydes. Pharmacological evaluation of benzotriazole and dibenzodiazepine derivatives for their clozapine-like properties revealed that dibenzodiazepine 11 bearing 4-bromophenyl group exhibited the same antipsychotic activity as the reference drug clozapine while the activity of benzotriazole 7 was $25 \%$ lesser than that of clozapine. Moreover, compounds 7 and 11 did not show significant CNS depressant activity as well as no or slight neurotoxicity on contrast to clozapine when tested in mice using forced swim, rotarod and horizontal screen tests.
\end{abstract}

Key Wonds: Benzotriazole. Dibenzodiazepine. Antipșy chotic activity

\section{Introduction}

One of the greatest healthy problems of modem psychopharmacology ${ }^{p}$ is a search for new antipsychotic drugs with a higher therapeutic efficiency and a wider spectrum of action on both positive and negative symptoms of schizophrenia as well as cognitive ones but with minimized adverse side effects. ${ }^{3}$ Traditional typical antipsychotic drugs. acting by a common mechanism of central dopamine (DA) D2 receptor blockade, are generally considered to be effective in the treatment of schizophrenics with positive symptoms. ${ }^{4}$ while a diversified group of the so-called atypical antipsychotic drugs expresses increased effectiveness in negative and cognitive symptoms."

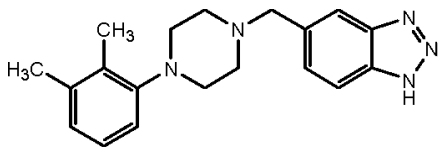

Benzotriazole $(A)$

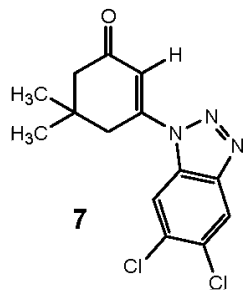

Among benzotriazole derivatives. compound (A) was reported to be potent atypical antipsychotic dnig ${ }^{5.6}$ due to the specific structure of its heteroaryl group. that mimics catechol moiety of the dopamine.

In addition. the clinically used drug clozapine, which is chemically dibenzodiazepine derivative is one of the most known aty pical neuroleptic agents which possess antimuscarinic, antiserotonergic, sedative and weak antidopaminergic properties.
Although the use of atypical antipsychotic drug clozapine in treatment of sclizophrenia avoided the main disadvantage of typical ones e.g. extrapyrinidal side effects, still its use is limited due to the ability to induce agramulocytosis sedation. dizziness. headache, nausea. voniting (neurotoxicity) and other side effects.
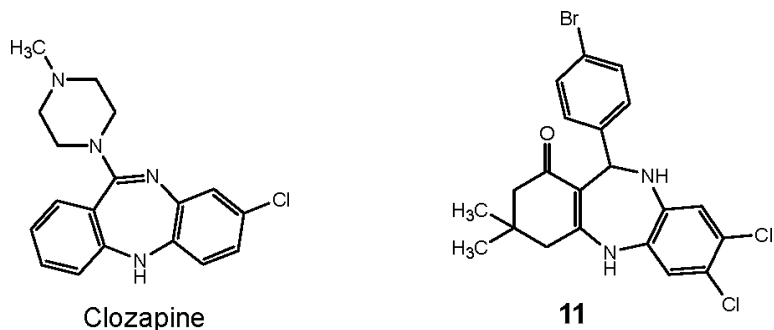

Based on the above facts. new compounds structurally related to the aforementioned benzotriazoles and dibenzodiazepines were synthesized with the aim to be clozapine-like antipsychotic but with lower side effects.

\section{Experimental}

Chemistry-Melting points were determined with a Gallenkamp (London. U. K.) melting point apparatus and are uncorrected. IR spectra (KBr. $\left.\mathrm{cm}^{-1}\right)$ were recorded on Bruker Vector. 22FT- IR (Fourier Transform Infrared (FTIR)) (Germany) spectrometer. ${ }^{1} \mathrm{H}$ NMR spectra were recorded on a Varian Genini-200 (200-MHz. Foster City, Calif., USA) and Varian Mercury-300 (300-MHz, City: Palo Alto. State: Calif.. USA) spectrometers using dimetlylsulphoxide (DMSO)- $d_{6}$ as a solvent and tetramethylsilane (TMS) as an internal standard 
(Chemical shift in ô. ppm). Mass spectra were determined using Mass spectrometers GC/MS Shimadzı QP 1000 EX (Shimadzı Corporation. Tokyo. Japan) with ionization energy $70 \mathrm{eV}$. Elemental analyses were determined using Automatic Elemental Analy zer CHN Model 2400 Perkin Elmer (USA) at Microanalytical Center. Faculty of Science, Cairo University. Egrpt. All the results of elemental analyses corresponded to the calculated values within experimental error. Progress of the reaction was monitored by thin-layer chromatography (TLC) using precoated TLC sheets with Ultraviolet (UV) fluorescent silica gel (Merck 60F254) and spots were visualized by iodine vapors or irradiation with UV light $(25+\mathrm{nm})$. All the chemicals were purchased from Sigma-Aldrich. The enaminones 1-3 were prepared according to the reported procedures. ${ }^{13.15}$

3-(2-Amino-4,5-dichlonophenylamino)-5,5-dimethylcyclohex-2-enone (4): A mixture of equimolar amounts (20 $\mathrm{mmol}$ ) of 5.5-dimethyl-1.3-cyclohexane dione and the 4.5-dichloro1.2-diaminobenzene was mixed well and then fused together at $120^{\circ} \mathrm{C}$ for $10 \mathrm{~min}$. The reaction mixture was cooled. triturated in hot dioxane and then filtered while hot. The obtained product was washed twice with dioxane $(20 \mathrm{~mL})$, dried and crystallized from ethanol $/ \mathrm{H}_{2} \mathrm{O}$. Yield: $80 \%:$ m.p.: $234-235^{\circ} \mathrm{C}$ (reported $^{\mathrm{l}+} 54 \%$ yield. m.p. : $218-219^{\circ} \mathrm{C}$ ): IR: $v 3473.3320$. $3190\left(\mathrm{NH} . \mathrm{NH}_{2}\right) .295 \mathrm{I}(\mathrm{CH}$. aliphatic). $1629(\mathrm{C}=\mathrm{O}) .1563(\mathrm{C}=\mathrm{C})$ $\mathrm{cm}^{-1}$. ${ }^{\mathrm{H}}$ NMR (300 MHz): ò $1.017\left(5,6 \mathrm{H}, 2 \mathrm{CH}_{3}\right) .2 .013(5,2 \mathrm{H}$, $\left.\mathrm{CH}_{2}\right) .2 .364$ (s. $\left.2 \mathrm{H}_{0} \mathrm{CH}_{2}\right)+637$ (s. $\mathrm{lH}$, vinylic $\mathrm{H}$ ) 5.325 (s. $2 \mathrm{H}$. $\mathrm{NH}_{3}$ exch.) $6.95 \mathrm{I}, 7.106$ (two s. 2H, ArH) 8.172 (s. $1 \mathrm{H}, \mathrm{NH}$. exch.). Analy sis for $\mathrm{C}_{14} \mathrm{H}_{16} \mathrm{Cl}_{2} \mathrm{~N}_{2} \mathrm{O}$ (299.20). Calcd.: C, 56.20; H. 5.39: N. 9.36: Found: C. 55.97: H. 5.09: N. 9.30

General procedure for preparation of compounds (5-8). An appropriate enaminone (1-4) (3 mmol) was dissolved in a mixture of $\mathrm{HCl}(1.5 \mathrm{~mL}, 37 \%)$. acetic acid $(10 \mathrm{~mL})$ and water $\left(5 \mathrm{~mL}\right.$ ) and then cooled at $0^{\circ} \mathrm{C}$. The reaction misture was diazotized using a cooled solution of $\mathrm{NaNO}_{2}(3 \mathrm{mmol})$ in water $(5 \mathrm{~mL})$. The reaction mixture was stirred for $30 \mathrm{~min}$ at $0^{\circ} \mathrm{C}$. Sodium acetate $(1.0 \mathrm{~g})$ was added and the mixture was stirred at $0^{\circ} \mathrm{C}$ for another $30 \mathrm{~min}$. The separated product was filtered, washed with water and crystallized.

3-(5-Chloro-1 $H$-benzo[d] $[1,2,3]$ triazo]-1-yl)cyclohex-2enone(5): Yield: $75 \%$; m.p. : $188-189^{\circ} \mathrm{C}$; Cry stallized from Et$\mathrm{OH} / \mathrm{H}_{2} \mathrm{O}$ : IR: v $3072(\mathrm{CH}$. aromatic), $2965(\mathrm{CH}$. aliphatic). $1679(\mathrm{C}=\mathrm{O}) \mathrm{cm}^{-1}$. ${ }^{\mathrm{l}} \mathrm{H}$ NMR $(200 \mathrm{MHz}):$ ò 2. $150-2.209(\mathrm{~m}, 2 \mathrm{H}$, $\left.\mathrm{CH}_{2}\right) .2 .50\left(\mathrm{~m}, 2 \mathrm{H}, \mathrm{CH}_{2}\right), 3.250-3.303\left(\mathrm{~m}, 2 \mathrm{H}, \mathrm{CH}_{2}\right), 6.530$ (s. 1H. vinylic H). $7.682-7.726$ (d, $J=8.8 \mathrm{~Hz}, 1 \mathrm{H}$. ArH), 8.077 8.122 (d. $J=9.0 \mathrm{~Hz}, 1 \mathrm{H}$. ArH), 8.372 (s. $1 \mathrm{H}, \mathrm{ArH}$ ). Analysis for $\mathrm{C}_{12} \mathrm{H}_{10} \mathrm{ClN}_{3} \mathrm{O}(2+7.68)$. Calcd: C. 58.19: H. 4.07: N. 16.97: Found: C, 57.93; H. 4.44; N, 16.71.

3-(1H-Benzo[d] [1,2,3]triazol-1-yl)-5,5-dimethylcyclohex2-enone(6): Yield: $80 \%$; m.p.: $88-89^{\circ} \mathrm{C}$ : Crystallized from benzene/pet ether (60/80): IR: $v 3056(\mathrm{CH}$ aromatic). 2947 (CH. aliphatic), $1662(\mathrm{C}=\mathrm{O}) \mathrm{cm}^{-1}{ }^{1} \mathrm{H}$ NMR $(200 \mathrm{MHz}): \delta 1.237$ $\left(\mathrm{s}, 6 \mathrm{H} .2 \mathrm{CH}_{3}\right) .2 .50$ (s. $\left.2 \mathrm{H}, \mathrm{CH}_{2}\right) .3 .316\left(\mathrm{~s}, 2 \mathrm{H} . \mathrm{CH}_{2}\right), 6.65+$ (s. $\mathrm{IH}$. vinylic $\mathrm{H}), 7.639-8.31(\mathrm{~m}, 4 \mathrm{H}, \mathrm{ArH})$. Analy sis for $\mathrm{C}_{1} \mathrm{H}_{15}$ $\mathrm{N}_{3} \mathrm{O}(2+1.29)$. Calcd: $\mathrm{C}, 69.69 ; \mathrm{H}, 6.27 ; \mathrm{N}, 17.41$ : Found: $\mathrm{C}$, 69.54: H. 5.99: N. 17.09

3-(5-Chlo ro- $1 H$-benzo[d][1,2,3]triazo]-1-y])-5,5-dimethylcyclohex-2-enone(7): Yield: $85 \%$ : m.p.: $190-191{ }^{\circ} \mathrm{C}$ : Crystallized from EtOH: ${ }^{1} \mathrm{H} N M R(300 \mathrm{MHz})$ : ò $\mathrm{l} .163$ (s. $6 \mathrm{H}, 2 \mathrm{CH}_{3}$ ).
2.428 (s. $\left.2 \mathrm{H} . \mathrm{CH}_{2}\right) .3 .211$ (s, $\left.2 \mathrm{H}_{1} \mathrm{CH}_{2}\right), 6.570$ (s, $1 \mathrm{H}$, vinylic H). $7.704-8.381(\mathrm{~m} .3 \mathrm{H} . \mathrm{ArH}$ ). MS: $m: z$ (rel. int.) $278(\mathrm{M}+3$. $0.5) .277(\mathrm{M}+2,7.0) .275\left(\mathrm{M}^{+}, 16.1\right) .164(16.6), 128(10.6)$. 83(100.0). Analysis for $\mathrm{C}_{14} \mathrm{H}_{1+} \mathrm{ClN}_{3} \mathrm{O}$ (275.73). Calcd.: $\mathrm{C}$, 60.98: H. 5. 12: N. 15.24: Found: C. 61.11: H. 5.20: N. 14.93.

3-(5,6-Dichlo ro-1 $H$-benzo[d] [1,2,3]triazo]-1-yl)-5,5-dimethylcyclohex-2-enone(8): Yield: $88 \%$ : m.p.: 187-188 "C: Crystallized from EtOH: IR: v 3063 (CH. aromatic). 2952 (CH, aliphatic), $1661(\mathrm{C}=\mathrm{O}) \mathrm{cm}^{-1} .{ }^{l} \mathrm{H}$ NMR $(200 \mathrm{MHz}): \delta$ 1.152 (s. $6 \mathrm{H}, 2 \mathrm{CH}_{3}$ ). 2.408 (s. $2 \mathrm{H}, \mathrm{CH}_{2}$ ). 3.175 (s. $2 \mathrm{H}, \mathrm{CH}_{2}$ ). 6.615 (s. $1 \mathrm{H}$, vinylic H), 8.472 (s. $1 \mathrm{H}$. ArH). 8.624 (s, $1 \mathrm{H}$, ArH). Analy sis for $\mathrm{Cl}_{1} \mathrm{H}_{1} \mathrm{Cl}_{2} \mathrm{~N}_{3} \mathrm{O}(3 \mathrm{10}$. 18). Calcd.: C. $54.2 \mathrm{l}$ : H. 4.22 ; N. 13.55: Found: C, $53.90 ;$ H. 4.42; N. 13.38 .

3-(2-Mercapto-1 $H$-benzo[d] imidazol-1-yl)-5,5-dimethylcyclohex-2-enone (10): The enaminone 2 (4 mmol) was stirred in ethanol $(20 \mathrm{~mL})$ containing potassium hydroxide ( $4 \mathrm{mmol})$ for $1 \mathrm{~h}$ until a clear solution was obtained. Carbon disulfide ( 6 numol) was added dropwise to the stirred reaction mixture and then it was heated under reflux for $2 \mathrm{~h}$. The reaction mixture was stirred at room temperature for $12 \mathrm{lh}$, cooled and then acidified with diluted $\mathrm{HCl}$. The separated product was filtered, washed with water and crystallized from $\mathrm{EtOH} / \mathrm{H}_{2} \mathrm{O}$. Yield: $82 \%$; m.p.: $147.1+8{ }^{\circ} \mathrm{C}$ : ${ }^{1} \mathrm{H}$ NMR (200 MHz): $\delta 1.222$ (s. $6 \mathrm{H}$, $2 \mathrm{CH}_{3}$ ). 2.506 (s. 2H. $\mathrm{CH}_{2}$ ). 2.90 (s. $2 \mathrm{H}, \mathrm{CH}_{2}$ ). 6.308 (s. $1 \mathrm{H}$, vinylic H). 7.314 (s, 3H. ArH). 13.188 (s. 1H, SH, exch.). MS: $m z$ (rel. int.) $275\left(\mathrm{M}^{-}+3.1 .2\right) .274\left(\mathrm{M}^{-}+2.5 .0\right) .273\left(\mathrm{M}^{+}+1\right.$. 3.3). $272\left(\mathrm{M}^{-}, 15.8\right), 188(100.0), 15 \mathrm{l}(17.4), 77(43.6)$. Analysis for $\mathrm{C}_{15} \mathrm{H}_{16} \mathrm{~N}_{2} \mathrm{OS}(272.37)$, Calcd.: C. 66.15; H. 5.92: N, 10.29: Found: C. 65.81: H, 5.65: N. 9.92.

General procedure for preparation of compounds (11-18). The enaminone 4 ( $3 \mathrm{mmol}$ ) was dissolved in ethanol ( $15 \mathrm{~mL}$ ) containing 10 drops of glacial acetic acid by gentle heating. The reaction mixture was allowed to cool to room temperature and then the appropriate aromatic aldehyde $(3 \mathrm{mmol})$ was added. The resulting mixture was allowed to stir at room temperature for $12 \mathrm{~h}$. The separated crystalline product was filtered, dried and crystallized from the appropriate solvent.

11-(4-B1omophenyl)-7,8-dichloro-3,3-dimethyl-2,3,4,5,10, 11-hexahydo- $H$-dibemo $[\mathrm{b}, \mathrm{e}][1,4]$ diazejin-1-one (11): Yield: 86\%; m.p.: $259-260^{\circ} \mathrm{C}$; Crystallized from EtOH; IR: v 3329 (NH). $2979\left(\mathrm{CH}\right.$, aliphatic), $1645(\mathrm{C}=\mathrm{O}), 1553(\mathrm{C}=\mathrm{C}) \mathrm{cm}^{-1}$. ${ }^{1} \mathrm{H}$ NMR (200 MHz): ô 1.019, 1.066 (two s. $6 \mathrm{H}, 2 \mathrm{CH}_{3}$ ). 2.064$2.278\left(\mathrm{~m}, 2 \mathrm{H}, \mathrm{CH}_{2}\right), 3.385$ (s. $\left.2 \mathrm{H}, \mathrm{CH}_{2}\right), 5.639-5.667$ (d. $J=$ $5.6 \mathrm{~Hz}, 1 \mathrm{H}$, benzylic $\mathrm{H}$, after $\mathrm{D}_{2} \mathrm{O}$ becomes $\mathrm{s}$ at 5.630$), 6.611$ 6.639 (d. $J=5.6 \mathrm{~Hz}$. 1H. NH. exch.). 6.761 (s. $1 \mathrm{H}$. ArH), $7.011-7.051$ (d. $J=8.0 \mathrm{~Hz}, 2 \mathrm{H}, \mathrm{ArH}) .7 .167$ (s. 1H, ArH). 7.374$7.41+($ d. $J=8.0 \mathrm{~Hz}, 2 \mathrm{H} . \mathrm{ArH}) .8 .985$ (s, 1H, NH, exch.). Analy'sis for $\mathrm{C}_{21} \mathrm{H}_{19} \mathrm{BrCl}_{2} \mathrm{~N}_{2} \mathrm{O}$ (466.20). Calcd. C. 54.10: H, 4.11: N. 6.01 ; Found: C. $53.78: \mathrm{H}, 4.43: \mathrm{N}, 5.81$

7,8-Dichloro-11-(4-chlorophenyl)-3,3-dimethyl-2,3,4,5,10, 11-hexahydo- $H$-dibemo $[\mathrm{b}, \mathrm{e}][\mathbf{1 , 4}]$ diazejin-1-one (12): Yield: 83\%; m.p.: $264-265^{\circ} \mathrm{C}$ : Crystallized from $\mathrm{EtOH} / \mathrm{H}_{2} \mathrm{O}$; IR v 3304, $3236(\mathrm{NH}), 3057(\mathrm{CH}$, aromatic), 2963 ( $\mathrm{CH}$. aliphatic). $1605(\mathrm{C}=\mathrm{O}) .1537(\mathrm{C}=\mathrm{C}) \mathrm{cm}^{-1}$. ${ }^{\mathrm{H}} \mathrm{H}$ NMR $(200 \mathrm{MHz}): \delta 1.011$, 1.062 (two s. $\left.6 \mathrm{H}, 2 \mathrm{CH}_{2}\right) .2 .053-2.263\left(\mathrm{~m}, 2 \mathrm{H}, \mathrm{CH}_{2}\right) .3 .370(\mathrm{~s}$.

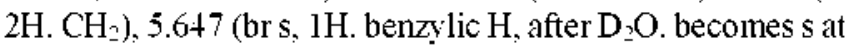
$5.6+1$ ), 6.605 (brs. 1H, NH. exch.), 6.750-7.267 (n. 6H. ArH). 8.972 (s. $\mathrm{lH} . \mathrm{NH}$. exch.). Analỵsis for $\mathrm{C}_{21} \mathrm{H}_{19} \mathrm{Cl}_{3} \mathrm{~N}_{2} \mathrm{O}(421.75)$. 
Calcd: C, 59.80; H, 4.54:N, 6.64: Found: C, 59.99; H, 4.78: N. 6.34 .

7,8-Dichlon-11-(4-fluomphenyl)-3,3-dimethyl-2,3,4,5,10, 11-hex ahy dm- $1 H$-dibenzo[b,e] $[1,4]$ diazepin-1-one(13): Yield: $78 \%$ : m.p.: $272-273^{\circ} \mathrm{C}$ : Crystallized from EtOH: IR: v $3422(\mathrm{NH}) .2958(\mathrm{CH}$. aliphatic). $165+(\mathrm{C}=\mathrm{O}) .15+1(\mathrm{C}=\mathrm{C})$ $\mathrm{cm}^{-1}{ }^{1} \mathrm{H}$ NMR (200 MHz): $\hat{o} 1.015,1.068$ (two s. $6 \mathrm{H}, 2 \mathrm{CH}_{3}$ ). 2.056-2.269 (m. $\left.2 \mathrm{H} . \mathrm{CH}_{z}\right) .3 .370$ (s. $\left.2 \mathrm{H} . \mathrm{CH}_{z}\right) .5 .654-5.679$ (d, $J=5.0 \mathrm{~Hz}$. $1 \mathrm{H}$. benzylic $\mathrm{H}$. after $\mathrm{D}_{2} \mathrm{O}$, becomes s at 5.645 ), $6.577-6.603$ (d. $J=5.2 \mathrm{~Hz} . \mathrm{lH} . \mathrm{NH}$. exch.). $6.741-7.139(\mathrm{~m} .6 \mathrm{H}$. $\mathrm{ArH}), 8.955$ (s, $1 \mathrm{H}$. NH. exch.). Analy sis for $\mathrm{C}_{21} \mathrm{H}_{19} \mathrm{Cl}_{2} \mathrm{FN} \mathrm{N}_{2} \mathrm{O}$ (405.29), Calcd: C. 62.23: H. 4.73: N. 6.91: Found: C. 62.07: H, 4.51: N, 6.63.

7,8-Dichloro-11-(4-hydroxyphenyl)-3,3-dimethyl-2,3,4,5, 10,11-hexahydro- $1 H$-dibenzo[b,e][1,+]diazepin-1-one (14): Yield: $80 \%$ : m.p.: $277.278^{\circ} \mathrm{C}$ : Crystallized from $\mathrm{EtOH} / \mathrm{H}_{2} \mathrm{O}$ : IR: $v 3350(\mathrm{OH}), 3321(\mathrm{NH}) .3058(\mathrm{CH}$ aromatic), $2960(\mathrm{CH}$. aliphatic). $1631(\mathrm{C}=\mathrm{O}), 1529(\mathrm{C}=\mathrm{C}) \mathrm{cm}^{-1} .{ }^{1} \mathrm{H}$ NMR $(200 \mathrm{MHz})$ : ò 1.017. 1.066 (two s. $6 \mathrm{H} .2 \mathrm{CH}_{3}$ ) $.2 .036-2.256$ (m. $2 \mathrm{H} . \mathrm{CH}_{3}$ ). $3.376\left(\mathrm{~s}, 2 \mathrm{H}, \mathrm{CH}_{2}\right) .5 .570-5.596(\mathrm{~d}, J=5.2 \mathrm{~Hz}, 1 \mathrm{H}$, benzylic $\mathrm{H}$, after $\mathrm{D} \approx \mathrm{O}$. becomes $\mathrm{s}$ at 5.568$), 6.453-6.483(\mathrm{~d}, J=6.0 \mathrm{~Hz}$, IH. NH. exch.) 6.515-7.111 (m. 6H. ArH). 8.857 (s. lH. NH. exch.), 9.162 (s. $1 \mathrm{H}, \mathrm{OH}$. exch.). Analysis for $\mathrm{C}_{21} \mathrm{H}_{20} \mathrm{Cl}_{2} \mathrm{~N}_{2} \mathrm{O}_{2}$ (403.30). Calcd: C. 62.54: H. 5.00: N. 6.95: Found: C. 62.21: H. 5.12: N, 6.79.

7,8-Dichlon-3,3-dimethyl-11-p-tolyl-2,3,4,5,10,11-hexahydro- $\mathbf{H}$-dibenzo[b,e][1,+]diazepin-1-one (15): Yield: 79\%: m.p.: $286-287^{\circ} \mathrm{C}$; Crystallized from EtOH: ${ }^{3} \mathrm{H}$ NMR $(300$ $\mathrm{MHz}$ ): $\delta 1.018 .1 .074$ (two s. $6 \mathrm{H} .2 \mathrm{CH}_{3}$ ) $.2 .117-2.192$ (m. $2 \mathrm{H}$. $\left.\mathrm{CH}_{2}\right) .2 .163\left(\mathrm{~s}, 1 \mathrm{H}, \mathrm{CH}_{3}\right) .2 .495-2.507\left(\mathrm{~m}, 2 \mathrm{H} . \mathrm{CH}_{2}\right) .5 .633-$ 5.653 (d. $J=6.0 \mathrm{~Hz}$. $1 \mathrm{H}$. benzylic $\mathrm{H}$. after $\mathrm{D}_{2} \mathrm{O}$. becomes s at $5.606) .6 .51+-6.534(\mathrm{~d}, J=6.0 \mathrm{~Hz}$. $1 \mathrm{H}, \mathrm{NH}$. exch.). $6.738-7.124$ (m. 6H. ArH). 8.869 (s. 1H. NH. exch.). Analysis for $\mathrm{C}_{2} \mathrm{H}$ $\mathrm{Cl}_{2} \mathrm{~N}_{2} \mathrm{O}(401.33)$. Calcd.: C. 65.84: H. 5.53: N. 6.98: Found: C. $65.74 ;$ H. $5.48 ;$ N. 7.02

11-(4-(Benzyloxy)phenyl)-7,8-dichloro-3,3-dimethyl-2,3, $4,5,10,11$-hexahydro- $1 H$-dibenzo[b,e][1,4] diazepin-1-one (16): Yield: $92 \%$ : m.p.: $158-159^{\circ} \mathrm{C}$ : Cry stallized from EtOH: IR: v $3301.3223(\mathrm{NH}) .3059(\mathrm{CH}$. aromatic). $2959(\mathrm{CH}$. aliphatic), $1610(\mathrm{C}=\mathrm{O}), 15+2(\mathrm{C}=\mathrm{C}) \mathrm{cm}^{-1} .{ }^{1} \mathrm{H}$ NMR $(200 \mathrm{MHz})$ : ô 1.032. 1.08 (two s. $6 \mathrm{H}, 2 \mathrm{CH}_{3}$ ), $2.058-2.274\left(\mathrm{~m}, 2 \mathrm{H}, \mathrm{CH}_{3}\right.$ ). $3.372\left(\mathrm{~s}, 2 \mathrm{H} . \mathrm{CH}_{2}\right) .4 .981\left(\mathrm{~s} .2 \mathrm{H}, \mathrm{OCH}_{2}\right), 5.628-5.654\left(\mathrm{~d}_{2} J=\right.$ $5.2 \mathrm{~Hz}$. $\mathrm{lH}$, benzylic $\mathrm{H}$ after $\mathrm{D}_{2} \mathrm{O}$ becomes $\mathrm{s}$ at 5.624$), 6.543-$ $6.570(\mathrm{~d} . J=5.4 \mathrm{~Hz}, 1 \mathrm{H}, \mathrm{NH}$, exch. $), 6.543-7.368(\mathrm{~m}, 11 \mathrm{H}$. ArH), 8.904 (s, lH, NH. exch.). Analysis for $\mathrm{C}_{38} \mathrm{H}_{\unlhd} \mathrm{Cl}_{\Sigma} \mathrm{N}_{2} \mathrm{O}_{2}$ (493.42) Calcd: C. 68.16: H. 5.31: N. 5.68: Found: C. 67.86: H, 5.25: N, 5.45.

7,8-Dichloro-3,3-dimethyl-11-phenyl-2,3,4,5,10,11-hexahydro- $1 H$-dibenzo[b,e][1,4]diazepin-1-one(17): Yield: $80 \%$ : m. p. : $293-294^{\circ} \mathrm{C}:$ Crystallized from EtOH/HzO $\mathrm{O}: \mathrm{MS}: m z$ (rel. int.) $386\left(\mathrm{M}^{-}-1.13 .8\right), 309(100.0), 199(22.2), 166(22.2) .133$ (33.3). 91 (55.6). Analysis for $\mathrm{C}_{21} \mathrm{H}_{20} \mathrm{Cl}_{2} \mathrm{~N}_{2} \mathrm{O}$ (387.30). Calcd.: C. 65.12: H. 5.20: N. 7.23:Found: C. 64.94: H. 4.88: N. 7.25 .

7,8-Dichlow-3,3-dimethyl-11-(thien-2-yl)-2,3,4,5,10,11hexahydro- $1 H$-dibenzo $[b, e][1,+]$ diazepin-1-one (18): Yield: 90\%: m.p. : $296-297^{\circ} \mathrm{C}$; Crystallized from EtOH; IR: v 3329 , $3237(\mathrm{NH}) .3068(\mathrm{CH}$, aromatic). 2967 (CH, aliphatic). 1630 $(\mathrm{C}=\mathrm{O}), 15+1(\mathrm{C}=\mathrm{C}) \mathrm{cm}^{-1} .{ }^{1} \mathrm{H}$ NMR $(200 \mathrm{MHz}): \delta 1.032,1.060$ (two s. $6 \mathrm{H} .2 \mathrm{CH}_{3}$ ). $2.060-2.299$ (m. $2 \mathrm{H}$. $\mathrm{CH}_{2}$ ), 2.408-2.639 (m. $\left.2 \mathrm{H}, \mathrm{CH}_{2}\right), 5.893-5.92 \mathrm{l}(\mathrm{d} . J=5.6 \mathrm{~Hz}$. lH. benzylic $\mathrm{H}$, after $\mathrm{D}_{2} \mathrm{O}$ becomes $\mathrm{s}$ at 5.895$) .6 .643-6.673(\mathrm{~d} . J=6.0 \mathrm{~Hz}, \mathrm{lH}, \mathrm{NH}$. exch.). 6.718-7.162 (m, 5H. ArH), 8.970 (s, lH. NH. exch.). Analy'sis for $\mathrm{C}_{19} \mathrm{H}_{18} \mathrm{Cl}_{2} \mathrm{~N}_{2} \mathrm{OS}$ (393.33). Calcd.: C. 58.02: $\mathrm{H}$. 4.61: N, 7.12 : Found: C. 57.86; H, 4.61: N, 7.14.

Phaumacological Studies-Male albino mice weighing 20-25 g were obtained from the Laboratory Animal Services Center, Faculty of Veterinary Medicine, Zagazig University. Zagazig. Egypt. The animals were maintained on a $12 \mathrm{~h}$-light/dark cycle under regulated temperature $\left(25 \pm 2^{\circ} \mathrm{C}\right)$ and humidity $(50 \pm$ $10 \%$ ) as well as fed with standard diet and water $a d$ libitum. They were allowed to acclintate seven days before use. This protocol was approved by the Animal Care and Use Committee of the Plarmacology department. Faculty of Veterinary Medicine. Zagazig University.

Ptosis test. It was carried out according to the method described by Chen and Bolner. ${ }^{16}$ Mice were divided into 15 equal groups $(\mathrm{n}=6)$. The first group was labelled as control and injected i.p. with the solvent (DMSO) while the second group was injected (i.p.) with clozapine at a dose of $3 \mathrm{mg} / \mathrm{kg}$. The tested compounds (5-8 and 10-18) were injected (i.p.) to the other groups at a dose of $3 \mathrm{mg} / \mathrm{kg}$. Every mouse was observed for the presence or absence of complete ptosis. The ptosis was rated as the fraction of the eyelid closure from normal. The ptosis ratio was made 4 for complete ptosis. 3 for $3 / 4$. 2 for $1 / 2$ and one for $1 / 4$ ptosis.

Forced swim pool test. The forced swin pool method (FSP) described by Porsolt. et al. ${ }^{13}$ was followed. Mice were classified into 15 groups. each of 6 and then injected i.p with solvent (control), reference drug clozapine and test compounds (5-8 and 10-18) at a dose of $3 \mathrm{mg} / \mathrm{kg}$ body weight $30 \mathrm{~min}$ before the test session. Two swim sessions were conducted. an initial 15 min pre-test followed by a $5 \mathrm{~min}$ test $24 \mathrm{~h}$ later. The animals were placed in a chamber (diameter: $45 \mathrm{~cm}$ : height: $20 \mathrm{~cm}$ ) containing water up to height of $15 \mathrm{~cm}$ at $25 \pm 2{ }^{\circ} \mathrm{C}$. The period of inmobility (passive floating without struggling and making only those movements which are necessary to keep its head above the surface of water) during the $5 \mathrm{~min}$ test period was measured and recorded.

Neunotoxicity screening. A-Rotanod test: Minimal motor impairment was measured in nice by the rotarod test. ${ }^{18}$ The mice were trained to stay on an accelerating rotarod that rotates at $4-10 \mathrm{rpm}$. The rod diameter was $3.2 \mathrm{~cm}$. Trained mice were classified into 15 groups, each of 6 and then injected i.p with DMSO (control), clozapine and test compounds (5-8 and 10-18) at a dose of $3 \mathrm{mg} / \mathrm{kg}$ body weight. Neurotoxicity was determined $30 \mathrm{~min}$ post treatment as the inability of the animal to maintain equilibrium on the rod for at least $1 \mathrm{~min}$ in each of three trials.

B-Horizontal screen test: Neural impairment was also determined by failure of nice to perform successfully the horizontal screen test. ${ }^{19}$ The apparatus consisted of a $13 \times 14 \mathrm{~cm}$ square wire screens which was mounted horizontally on a steel rod. The rod was supported at both ends and could be inverted through an arc of $180^{\circ}$. Untrained mice were classified into 15 groups, each of 6 and then injected i.p with DMSO (control). clozapine and test compounds (5-8 and 10-18) at a dose of 3 
$\mathrm{mg} / \mathrm{kg}$ body weight. The animals were placed individually on the top of the screen and the rod was then rotated (mice unable to climb to an upright position within $1 \mathrm{~min}$ were rated as failures 30 min after drugs administration, two values were recorded: (A) The number of mice that fall from the screen and (B) The number of mice that fail to climb the top of the screen (i.e. the sum of those that remain clinging to the bottom of the screens and those that falls from the screen).

Pentylenetetrazole seizure pattem test (PTZ). Mice were divided into 15 equal groups $(n=6)$. The first group was injected i.p. with DMSO (control) while clozapine and tested compounds were injected (i.p.) to the other groups at the same dose level.

The anticonvulsant activities of the compounds were determined against pentỵlenetetrazole-induced seizures "one hour later, mice were injected with pentylenetetrazole $70 \mathrm{mg} / \mathrm{kg}$ subcutaneously in scnuff of neck. After 2-4 min of PTZ injection. the animals develop sequence of excitement. myoclonic jerks. clonic seizures. one or more maximal tonic seizures and finally death. Seizure latency was defined as the time elapsed from injection of PTZ to the first two the myocloic jerks of the forelimbs. This has been considered to be the first sign of the beginning of seizure activity. ${ }^{2 l}$ Animals devoid of generalized convulsions were considered to be protected and their results were represented as protection (\%).

\section{Results and Discussion}

Chemistry. In this article. the new benzotriazole and dibenzodiazepine derivatives were synthesized as shown in Schemes 1 and 2 .

The valuable enaminone intermediates 1-3 were synthesized by condensation of equimolar amounts of the respective 1.2diaminobenzene derivative with 1.3-cyclohexanedione or its 5.5-dimethyl derivative through heating the reactants at reflux in toluene for 3 hours as reported. ${ }^{13-15^{5}}$ The enaminone + was obtained in a higher yield ( $80 \%$ ) than the previously reported one $(54 \%)^{1+}$ by fusion equimolar amounts of 5.5-dimethỵl1.3-cyclohexanedione and 4.5-dichloro-1.2-diaminobenzene together at $120^{\circ} \mathrm{C}$ for $10 \mathrm{~min}$. The 1,2-diaminobenzene reacts satisfactorily in this way provided that a $1: 1$ molar ratio of the reactants was used whereas no bis side products of the reaction of two molecules of 1.3-cyclic diketones and one molecule of the respective amine ${ }^{t *}$ was noticed.

We aimed to prepare new series of dibenzotriazepin-4-one (9) to explore their potential antipsychotic activity but unexpectedly $1 \mathrm{H}$-benzo[d] [1,2.3] triazole derivatives (5-8) were obtained (Scheme 1).

The novel benzotriazole derivatives (5-8) were synthesized in $75-88 \%$ y ields through diazotization of the aromatic amino group of the appropriate enaminones $(1-4)$ at $0^{\circ} \mathrm{C}$ using $\mathrm{HCl}$ and cooled solution of $\mathrm{NaNO}_{2}$. The formed diazonium salts was internally coupled preferably with imino group at position 3 rather than the active methylene at 2-position to give the benzotriazole derivatives (5-8) rather than the target dibenzotriazepin-4-one (9).

The structures of the $1 \mathrm{H}$-benzo [d] $[1.2,3]$ triazole derivatives (5-8) were confirmed using elemental analyses. IR and ${ }^{1} \mathrm{H}$
NMR spectra. IR spectra showed the disappearance of both absorption bands at $v=3473.3320$ and $3190 \mathrm{~cm}^{.1}$ due to the amino and imino groups of the starting enaminones. ${ }^{1} \mathrm{H}$ NMR showed the disappearance of both singlet peaks at $\hat{o}=\mathbf{5 . 3 2 5}$

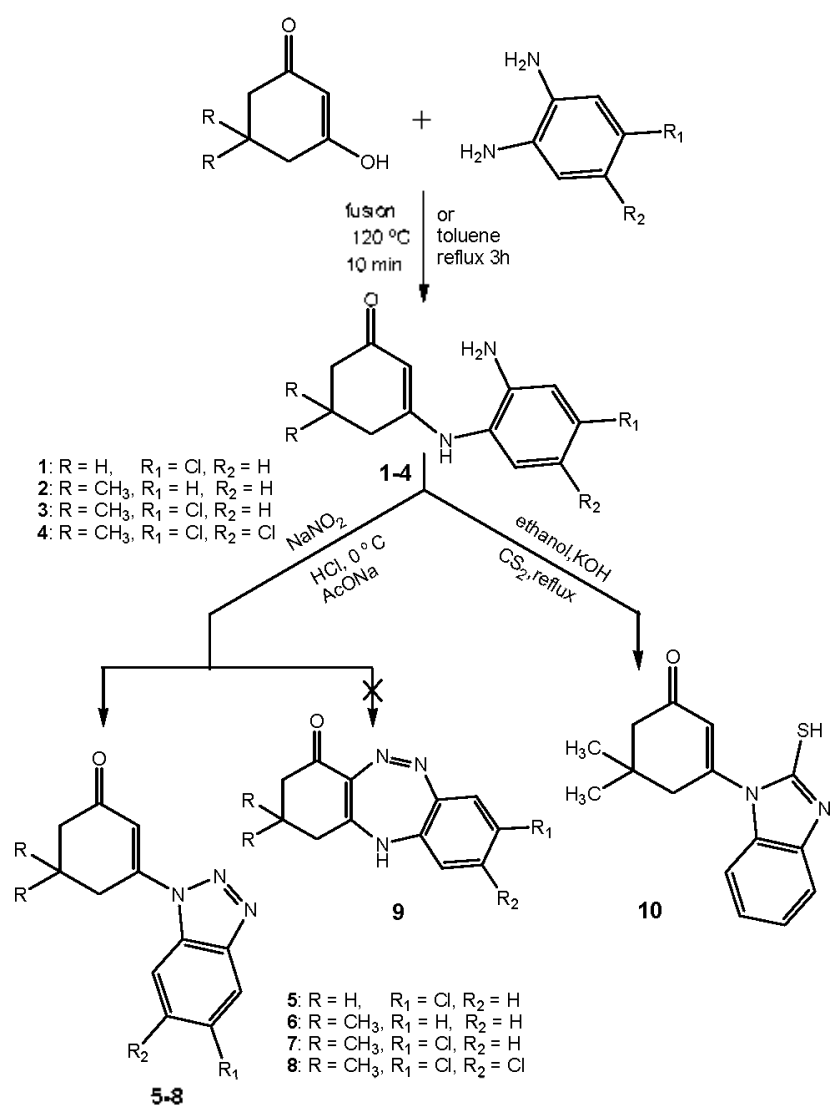

Scheme 1. Synthetic pathway for preparation of compounds 1-8 and 10

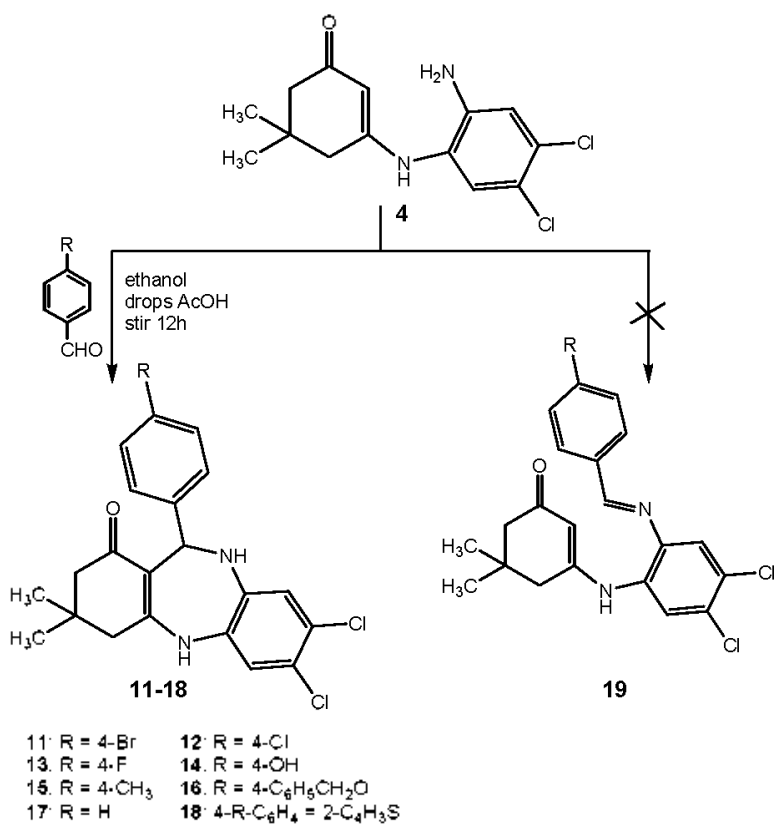

Scheme 2. Synthetic pathway for preparation of compounds 1118 
ppm for the amino group as well as at $\delta=8.172 \mathrm{ppm}$ due to the $\mathrm{NH}$ group of the starting enaminones. In addition. the appearance of a very characteristic singlet peak at about $\delta=6.5 \mathrm{ppm}$ integrating one proton due to the vinylic proton at 2-position meanwhile the disappearance of singlet peak at $\hat{\delta}=8.172 \mathrm{ppm}$ of the $\mathrm{NH}$ group of the starting enaminones represents an evidence for the formation of the benzotriazole derivatives rather than the target dibenzotriazepin-4-one (9).

Moreover, the novel 2-mercapto-benzo[d]imidazole (10) was obtained through cyclization of the enaminone 2 using carbon disulphide in hot ethanolic potassium hydroxide solution.

The novel dibenzodiazepine derivatives 11-18 in Scheme 2 were prepared via intemal . Fannich reaction ${ }^{13.1+, 23}$ by allowing the enaminone 4 to react at room temperature with different aromatic aldehydes in ethanol containing drops of glacial acetic acid. The high reactivity of the enaminone 4 towards the aldehydes can be attributable to the enaminone structure in which $\alpha$-position is particularly reactive to electrophilic reagents. ${ }^{3}$ This one-pot reaction was characterized by affording pure products with higher yields $(78-92 \%)$ due to it avoided separation of the in situ formed intermediate 19.

The structures of dibenzodiazepines 11-18 were characterized using elemental analy ses. IR. ${ }^{\mathrm{H}} \mathrm{H}-\mathrm{NMR}$ and mass spectroscopic methods. ${ }^{l} \mathrm{H}-\mathrm{NMR}$ showed no singlet at $\delta=5.325$ ppm for the amino group as well as no singlet at $\hat{\delta}=8.172 \mathrm{ppm}$ of the $\mathrm{NH}$ group of the starting enaminone. In addition the appearance of very characteristic doublet peak at $\delta=5.6 \mathrm{ppm}$ integrating one proton of the benzylic $\mathrm{H}$ at position $1 \mathrm{I}$ as well as another doublet peak at $\grave{\delta}=6.6 \mathrm{ppm}$ integrating one proton of the $\mathrm{NH}$ at 10-position of the dibenzodiazepine skeleton. It was observed also that the doublet peak of the benzylic $\mathrm{H}$ becomes singlet upon addition of $\mathrm{D}_{2} \mathrm{O}$ due to the disappearance of the neighbouring $\mathrm{NH}$ proton at 10 -position.

Phamacological studies. The newly synthesized compounds 5-8 and 10-18 were tested for their antipsychotic activities wia ptosis test ${ }^{16}$ using clozapine as a reference drug. In addition. the CNS depressant activities for such compounds were also examined using forced swim pool test. ${ }^{1 \%}$ Also. their neurotoxi-

Table 1. Effect of test compounds and clozapine ( $3 \mathrm{mg} / \mathrm{kg}$, i.p.) on mice using ptosis test

\begin{tabular}{clr}
\hline Compounds & Ptotic scoring & \% effect \\
\hline Control & 0 (No ptosis) & 0.0 \\
5 & $1(1 / 4$ ptosis) & 50.0 \\
6 & $2(1 / 2$ ptosis $)$ & 50.0 \\
7 & $3(3 / 4$ ptosis $)$ & 75.0 \\
8 & $3(3 / 4$ ptosis $)$ & 75.0 \\
10 & $1(1 / 4$ ptosis $)$ & 25.0 \\
11 & $4($ complete $p$ tosis $)$ & 100.0 \\
12 & $2(1 / 2$ ptosis $)$ & 50.0 \\
13 & $1(1 / 4$ ptosis $)$ & 25.0 \\
14 & $3(3 / 4$ ptosis $)$ & 75.0 \\
15 & $3(3 / 4$ ptosis $)$ & 75.0 \\
16 & $1(1 / 4$ ptosis $)$ & 25.0 \\
17 & $0($ No ptosis $)$ & 0.0 \\
18 & $2(1 / 2$ ptosis $)$ & 50.0 \\
Clozapine & $4($ complete ptosis $)$ & 100.0 \\
\hline
\end{tabular}

city was determined using both rotarod ${ }^{18}$ and horizontal screen $^{19}$ tests. These compounds were also screened for their anticonvulsant activities against penty lenetetrazole (PTZ) induced seizures. ${ }^{?(1}$ This is to explore the highly active compound as antipsychotic with least side effects in comparison with reference drug clozapine.

It was observed from Table I that compound 11 which bearing 4-bromophenyl group belonging to the dibenzodiazepine group showed the same antipsychotic activity as the reference drug clozapine whereas they caused complete ptosis in mice at a dose $\mathrm{e}^{24}$ of $3 \mathrm{mg} / \mathrm{kg}$ body weight. Moreover, other dibenzodiazepine derivatives containing 4-hydroxyphenyl (14) or 4methylphenyl substituents (15) as well as the benzotriazole derivatives bearing 5-chloro group (7) or 5,6-dichloro groups (8) showed a high antipsychotic activity but their values still $25 \%$ lesser than that of the reference drug clozapine (Table 1 ).

The results presented in Table 2 revealed that in general. conpounds $5,8,12,13,15$ and clozapine caused significant CNS depressant activity in mice upon using forced swim test as indicated from their higher immobility times. Other derivatives showed nonsignificant change in the immobility time and so, these derivatives may be useful as antidepressants.

In addition, the neurotoxicity for such novel compounds were determined using both rotarod and horizontal screen tests in comparison with the reference drug clozapine (Tables 3. 4). Through analy sis of Table 3 . it was observed that compounds $7,10-12,14$ and 16 showed no neurotoxicity at all while clozapine exhibited the lughest toxicity in mice at a dose level of $3 \mathrm{mg} / \mathrm{kg}$ upon using rotarod test.

It was observed from the results presented in Table 4 that dibenzodiazepine 16 showed neither severe (A) nor minor (B) neurotoxicity at all while clozapine exhibited the lughest severe toxicity (A) on using horizontal screen test. It was noted that severe neurotoxicity (A) increased in the order 15. $16>7,10,11.13>6.8 .17,18$.

Table 2. Effect of test compounds and clozapine ( $3 \mathrm{mg} / \mathrm{hg}$, i.p.) on mice using the forced stim test

\begin{tabular}{ccc}
\hline \multirow{2}{*}{ Compounds } & \multicolumn{2}{c}{ Immobility time (seconds) } \\
\cline { 2 - 3 } Control & before treatment & ${ }^{a}$ post treatment \\
\hline 5 & $128 \pm 5.3$ & $123 \pm 6.4$ \\
6 & $123 \pm 3.1$ & $135 \pm 5.0^{*}$ \\
7 & $123 \pm 6.1$ & $134 \pm 6.2$ \\
8 & $122 \pm 4.1$ & $125 \pm 5.2$ \\
10 & $130 \pm 5.1$ & $151 \pm 7.2^{\circ}$ \\
11 & $129 \pm 4.3$ & $128 \pm 3.5$ \\
12 & $122 \pm 5.1$ & $125 \pm 6.2$ \\
13 & $123 \pm 5.2$ & $153 \pm 5.4^{*}$ \\
14 & $120 \pm 3.5$ & $144 \pm 3.3^{*}$ \\
15 & $125 \pm 3.2$ & $122 \pm 4.6$ \\
16 & $127 \pm 3.4$ & $154 \pm 4.3^{*}$ \\
17 & $127 \pm 6.2$ & $133 \pm 8.4$ \\
18 & $126 \pm 7.1$ & $123 \pm 6.2$ \\
Clozapine & $124 \pm 3.3$ & $122 \pm 4.2$ \\
\hline
\end{tabular}

${ }^{*} P \propto 0.05$ compared with pre-treated group (Independent-sample T test ). Eacl 1 alue represents the mean \pm S. D. of 6 animals. ${ }^{a}$ After 30 min from injection reference drug or tested compounds. 
Table 3. Rotarod test in mice injected by the test compounds or clozapine ( $3 \mathrm{mg} / \mathrm{kg}$ i.p)

\begin{tabular}{cc}
\hline & "Rotarod toxicity \\
\cline { 2 - 2 } Compond & $30 \mathrm{~min}$ \\
\hline Control & $0 / 6$ \\
$\mathbf{5}$ & $3 / 6$ \\
7 & $2 / 6$ \\
8 & $0 / 6$ \\
10 & $2 / 6$ \\
11 & $0 / 6$ \\
12 & $0 / 6$ \\
13 & $0 / 6$ \\
14 & $4 / 6$ \\
15 & $0 / 6$ \\
16 & $1 / 6$ \\
17 & $0 / 6$ \\
18 & $2 / 6$ \\
Clozapine & $1 / 6$ \\
\hline
\end{tabular}

"Rotarod toxicity (number of animals exhibiting toxicity number of animals tested). Each value represents the mean $\pm S$. D. of 6 animals.

Table 4. Horizontal screen test in mice injected by the test compounds or clozapine ( $3 \mathrm{mg} / \mathrm{kg}$ i.p)

\begin{tabular}{ccccc}
\hline & A & $\%$ Neurotoxicity & B & $\%$ Nenrotosicity \\
\hline Control & $0 / 6$ & 0 & $0 / 6$ & 0 \\
$\mathbf{5}$ & $3 / 6$ & 50 & $1 / 6$ & 16.7 \\
$\mathbf{6}$ & $2 / 6$ & 33.3 & $1 / 6$ & 16.7 \\
$\mathbf{7}$ & $1 / 6$ & 16.7 & $1 / 6$ & 16.7 \\
$\mathbf{8}$ & $2 / 6$ & 33.3 & $1 / 6$ & 16.7 \\
$\mathbf{1 0}$ & $1 / 6$ & 16.7 & $1 / 6$ & 16.7 \\
$\mathbf{1 1}$ & $1 / 6$ & 16.7 & $1 / 6$ & 16.7 \\
$\mathbf{1 2}$ & $4 / 6$ & 66.7 & $2 / 6$ & 33.3 \\
$\mathbf{1 3}$ & $1 / 6$ & 16.7 & $0 / 6$ & 0 \\
$\mathbf{1 4}$ & $4 / 6$ & 66.7 & $2 / 6$ & 33.3 \\
$\mathbf{1 5}$ & $0 / 6$ & 0 & $4 / 6$ & 66.7 \\
$\mathbf{1 6}$ & $0 / 6$ & 0 & $0 / 6$ & 0 \\
$\mathbf{1 7}$ & $2 / 6$ & 33.3 & $0 / 6$ & 0 \\
$\mathbf{1 8}$ & $2 / 6$ & 33.3 & $1 / 6$ & 16.7 \\
Clozapine & $6 / 6$ & 100 & $0 / 6$ & 0 \\
\hline
\end{tabular}

$A=$ number of mice fall from the screen. $B=$ number of mice that fail to climb the top of the screen.

It was found that all compounds (5-8 and 10-18) and also clozapine can not protect animals against pentylenetetrazole (PTZ) induced seizures and so, these compounds were considered to be devoid of any anticonvulsant activity.

It is apparent from Table 1 that compounds 11. 7.8.14 and 15 were the most active ones. It was noted also that the antipsychotic activity of dibenzodiazepine 11 bearing +-bromophenyl group was equal to that of the reference drug clozapine (Table 1) but it was characterized by being almost devoid from many side effects which often associated with clozapine treatment such as prolonged sedation (Table 2) and neurotoxicity (Tables 3. 4).

It was also noted that benzotriazole 7 had the same antipsychotic activity as its dichloro analog 8 but it had no or lesser neurotoxicity than 8 . In addition, the dichloro derivative
8 caused a significant sedation as evidenced by its longer immobility time on contrast to its chloro analog 7 (Table 2). Thus. benzotriazole 7 is preferred than its dichloro analog 8 or clozapine as safe antipsychotic agent

Indeed. the halogen substituent in different antipsychotic diarylazepine analogs has been considered as an important structural element in the drug-receptor interaction ${ }^{36}$ Its favourable influence might be related not only to electron-withdrawing effect but also the increased lipophilicity. ${ }^{27}$ Thus. the two chloro groups of benzotriazole 8 may be responsible for its higher lipoplilicity and subsequently its ligher neurotoxicity or its prolonged sedation over that of the monochloro benzotriazole 7

Regarding compounds 14 and 15 . they share both the antipsychotic activity (Table l) and also the higher neurotoxicity side effects (Table 4 ) but the only difference lies in their effects on immobility time whereas dibenzodiazepine 15 bearing 4-methylphenyl group is more lipopluilic and subsequently it caused prolonged sedation than its candidate $1+$ which bearing 4-hydroxyphenyl polar group (Table 2).

\section{Conclusion}

It could be concluded that new benzotriazole (5-8) and dibenzodiazepine (11-18) derivatives were synthesized from 3-[(2-amino-4.5-disubstituted phenyl)amino]-5.5-disubstitutedcyclohex-2-enones (1-4) with high purity and excellent yields. Dibenzodiazepine 11 which bearing t-bromophenyl group had the same antipsychotic activity as clozapine but with lesser side effects whereas it showed nonsignificant CNS depressant activity on using forced swim test as well as no or slight neurotoxicity on contrast to clozapine which showed the highest neurotoxicity upon using rotarod or horizontal screen tests. Among benzotriazoles. compound 7 showed the highest antipsychotic activity without causing significant sedation or neurotoxicity which often accompanied clozapine treatment when tested in mice at a dose of $3 \mathrm{mg} / \mathrm{kg}$ body weight. All compounds were devoid from any anticonvulsant activity and clozapine as well.

\section{Refeiences}

1. Amitai. N.: Semenova. S.: Markou. A. Em. J. Phamacol. 2009. 602,78

2. McEvor, J. P. J. Clin. Psychiatry 2007, 68 (Suppl. 14), 4.

3. Maehara, S.; Hikichi, H: Satow, A: Okuda, S; Ohta, H. Phamacol Biochem. Behav 2008, 91, 140

4. Wiesel, F. A. Br. J. Psvchiat. 1994, 164,65.

5. Tomić, M.; Kundaković, M; Butorović, B.; Janać, B.; Andrić, D.; Roglić, G.; Ignjatović, D.; Kostić-Rajacić, S. Bioorg. Med. Chem. Lett. 2004, 14, 4263 .

6. Caliendo, G.: Greco, G.: Grieco, P.: Novellino, E.: Perissuttil, E.: Santagada, V.; Barbarulo, D.; Esposito, E.; DeBlasi, A. Eutr $J$. Med. Chent 1996,31, 207.

7. Liegeois, J. F. F.; Bruhwyler, I,; Rogister, F. A.; Delarge, J. E. Cur. Med. Chem 1995, 1,471

8. Liegeois, J. F. F.: Bruhwyler, J.; Damas, J : Nguyen, T. P.; Chleide, E. M. G.; Mercier, M. G. A.; Rogister, F. A.; Delarge, T. E. J. Hed. Chem. 1993, 36, 2107.

9. Meltzer, H. Y.: Li, Z.: Kaneda, Y.: Ichikawa, J. Prog. Nenropsycho. Phamacol. 2003, 27, 1159 . 
10. Ichikawa, J.: Ishii, H.: Bonaccorso, S.; Fowler, W. L.; O Laughlin, I. A.: Meltzer, H. Y. J. Neurochem. 2001, 76, 1521.

11. Bantick, R. A.; Deakin, J. F.: Grasby, P. M. J. Psychopharmacol. 2001, 15, 37

12. Burris, K. D.; Molski, T. F.; Xu, C.: Ryan, E; Tottori, K.; Kikuchi, T: Yocca, F. D.: Molinoff, P. B. J. Phamacol Exp. Ther: $2002,302,381$

13. El-Sabbagh, O. I.: Abd-El Alim, A. F. Zag. J. Pham. Sci. 2000, 9, 9.

14. Tonkikh, N. N.; Strakovs, A.: Rizhanova, K. V: Petrova, M. V. Chem. Heterocycl Comp 2004, 10,949.

15. Kametani, T.; Ihara, M.; Takahashi, K. Chem. Pham. Bull. 1972, 20,1588 .

16. Chen, G.: Boluner, B. Cited in Screening tethods in Phamacologv, 1st Ed: Academic Press: New York and London, 1965; 182.

17. Porsolt, R. D.: Anton, G.: Blanet, N.: Talfie, M. Eur. J. Pharmacol $1978,47,379$.
18. Dunham, N. W.; Miya, T. S. J. Am. Pham .Assoc. Sci. Ed. 1957, 46.208.

19. Coughenour, L. L.; Mclean, I. R.: Parker, R. B. Phamacol. Biochent Behat $1977,6,351$.

20. Fisher, R. S. Brain Res. Rev 1989, 14, 245.

21. Osonoe, K.; Mori, N.: Suzuki, K:; Osonoe, M. Brain Res. 1994. $663,338$.

22. Greenhill, T. V. J. Chem. Soc. Perkin I 1976, 2207.

23. Greenhill, I. V. Chem. Soc. Rev 1977, 6, 277.

24. Wiley, T. L. Euro. J. Phamacol 2008, 578, 216.

25. Mao, Q.-Q; Ip, S.-P.: Tsai, S.-H.: Che, C.-T. J. Ethopharmaco$\log 22008,119,272$

26. Froimowitz, M.; Ramsby, S. J. Hed Chem. 1991, 34, 1707.

27. Liegeois, T. F. F.: Rogister, F. A.; Bruhwyler, T.; Damas, T.; Nguyen, T. P.; Inarejos, M. O.; Chleide, E. M. G.: Meroier, M. G. A.: Delarge, I. E. J.Med Chem 1994, 37, 319 